\title{
DIAGNOSTIC SIGNIFICANCE OF VESTIBULAR AND AUDITORY FUNCTION TESTS IN PATIENTS WITH CEREBRAL APOPLEXY
}

NOBUHITO TOKITA, M.D.

Department of Otorhinolaryngology, School of Medicine, Showa University, Tokyo

(Director: M. Okamoto, M.D.)

Of 143 appoplectic patients who were studied by neuro-otological tests, 50 cases whose cerebral lesions were detected by cerebral angiography, brain scintigraphy and neurological examinations, were selected for the following investigations;

1) The relationship between affected site of the brain and abnormal neuro-otological findings.

2) Diagnostic significance of neuro-otological tests for evaluating the sequela of apoplexy

3) Diagnostic significance of neuro-otological tests for the detection of abnormality of vestibular system in the brain stem, especially the supratentorial lesion.

The results obtained were as follows:

1) Nystagmus was observed in approximately half the cases of cerebral hemorrhage without distinct difference between lateral and combined type. This is presumably due to the secondary effect on the brain stem.

2) In optokinetic pattern test (OKP test), the abnormal findings were observed more frequently in the combined type of cerebral hemorrhage than in the lateral type. It is useful to localize the site of hemorrhage.

3) In about half the cases of cerebral hemorrhage, abnormal findings were obtained in interaural differentiation test in both lateral and combined type. The abnormality in the interaural differentiation test suggests the extension of the lesion and if aphasia developed, the site of hemorrhage extends beyond the cerebral subcortex to the cerebral cortex.

4) Nystagmus was observed in more than half the cases of cerebral infarction, but no definite correlation was recognized between the occlusion site and... appearance of any special type of nystagmus.

5) The OKP findings were abnormal in all patients with the major cerebral artery occlusion. This is due to the size of cerebral infaction in the cerebral hemisphere.

6) In many patients OKP test and interaural differentiation test could not performed. This probably due to the size of the supratentorial lesion.

From these results, it is concluded that the vestibular and auditory function tests as well as the neurological tests may be useful in the diagnosis of exact site and extension of the cerebral lesion, and to find out the presence and degree of brain stem lesion, and to presume the prognosis of the apoplectic patients.

$$
79 \mathrm{~A}-0645, \quad 11522
$$

\section{脳卒中患者に対する前庭系および聴覚系検査の診断学的意義}

一一腷血管写抢よび脳シンチグラフィーからの教察も含めて——

昭和大学医学部耳鼾咽燋科学教室（主任：岡本途也教授）

時田信 仁 


\section{Iはじめに}

めまい, 平衡障害, 難聴の診断は, 近年の神経耳科学 の進歩により，その対象が应大された，すなわち，内耳 を形成している蝸牛や前庭器官の障害ばかりでなく，第 8 腷神経系の障害を指標として, 脳幹や小脳を含如た中 枢神経系の障害の診断にまで広げられた，天幕下領域の 障害に対しては，病栄局在診断としての神経耳科学の意 義はすでに確立され，数多く報告されている。しかし， 天幕上に障害の多い脳卒中症例に対しては神経耳科学的 見地加らの考察齐加えた報告は少ない，故に著者は檤血 管撮影や脳シンチグラフィーより障害部位を推定し, 神 経耳科学的検查といかなる関倸にあるかを調心゙た。す わち,

(1) 障害された腷の部位と神経耳科学的異常所見との関 倸.

（2）急性期を過ぎた脑卒中後遺症例に対する神経耳科学 の診断学的価值.

（3）中枢前庭采障害，とくに天幕上の障害に扔ける神経 耳科学の診断学的意義について検討したので報告す る.

\section{II 对象および険查方法}

研究対象は昭和48年12月上り昭和50年 3 月までの1年 3 ケ月間に, 太田綜合病院附属熱海総合病院に, リ八ビ リテーションを目的として入院した脳卒中㣪遗疾患者 中，神経耳科学的諸検查を施行し得た 143 例で，そのう ち媨血管撮影, 檤シンチグラフィーにより障害部位を診 断し得たものは50例である. 但し, 前庭平衡機能検査が 不可能であつたもの，および末梢迷路障害と診断された ものは研究対象より除外した。 しかし，他党的梌监で る前庭平衡機能検查は可能であつたが，自覚的検查であ る聴覚検查は不可能であつた症例については，一つの重 要な所見として研究対象に入れた。 その理白は，脳主幹 動脈の閉塞例の子学扱つた媨硬塞症例中には，重症で失 語症などを伴っていた症例があったために，聴觉検查は 不可能であつたからである。

研究対象の内訳は，男27例，女23例であり，年龄は20 歳代 4 例，30歳代 6 例，40歳代 11 例，50歳代 9 例，60歲 代16例，70藏代 4 例，以上の50例である。

検查方法
A. 神経耳科学的部位骖断法
I. 前庭平衡機能娭查
(1) 眼振検查

注視眼振は腿前 $50 \sim 70 \mathrm{~cm}$ で正面, 左右上下 30 度の方
向を注視させて調べた，非注視眼振はフレンツェルの眼 鏡を装用し，座位正面視の状態で眼振を観察した。誘発

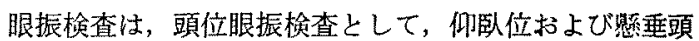
位で行ない，頭位変換眼振検查は Stenger 法および Dix-Hallpike 法で行なつた.

(2) 視運動性眼振検査

視運動性眼振の刺激装置は $\mathrm{Ohm}$ 型を使用し, 刺激 方法は毎秒 4 度の正の等角加速度で加速し, 毎秒 160 度 まで達し，その後，每秒 4 度の負の等角加速度で減速 し，○に到る方法を使用した。 これを電気眼振部で時定 数を原波形では 3.0 , 微分波形では0.03として, 記録計 の紙送りを $0.1 \mathrm{~cm} / \mathrm{sec}$ と $0.5 \mathrm{~cm} / \mathrm{sec}$ で記録した。 0.1 $\mathrm{cm} / \mathrm{sec} の$ ときは，一つのパターンとしてみる Optokinetic Pattern (OKP) で判定した.

OKP 所見は, (1)眼振緩徐相速度の上昇，(2)視連動性 刺激に対する反応の程度, (3)fusion limit の低下の有 無，(4)左右羙，以上 4 項目を判定基準とし，不良例とは 眼振緩徐相速萃の上昇および反応が不良であり，著明な 左右差を示した例である．境界例は上記項目中，(1)(2)(3) 上もにやや不良であるが，左右差は認め難いものであ る.

\section{II. 恥覚検查}

純音聴力蚞查, 語音明睹度検查の他に, 昭和大学耳鼻 咽喉科学教空で行っている特殊聴力検査を行つた．特殊 聴力検查核次の構成からなっている。

(1) 万向感検查 (21 組)

(2)右側, 左側昰語音明睆度検査

(3)両耳時閒歪語音合成能検查

(4)両耳分碓能楧查 (10組)

$$
\text { である゙ }
$$

症例によつて，バケシー自記オージオメトリーを追加 した.

そのらち著者は両耳分陮能検查をとりあげ，障害部位 診断の判定に資した，我々の教室で行っている両耳分離 能娭查では，0３0\% を異常例，40７0\% を境界例，80 \%以上泟常例としている。吻論，境界例として扱つた 40７0\%の幅が問題上なるが，被検者の純音聴力および 数字明瞭度考参考にして判定した。

B. 放射線学的部位診断法

(1)脑血管撮影法

脳血管撮影は脳卒中症例を検查対象としているので， 内頸動脈領域の頭蓋内血管を造影する頸動脈撮影 carotid angiography (CAG) を施行した。著者は天幕上障 
害部位を診断することを目的としたために椎骨動脈撮影 （VAG）は省略した。

(2) 脳シンチグラフィー

核種として ${ }^{99} \mathrm{~m} \mathrm{TcO} \overline{4}$ (pertechnetate) を静注し、シン チカメラで撮影した。

C. 障害部位判定法

大媨半球出血例は，内包を中心として外側すなわち内 包，線状体を含めた部位に出血のあつたものを外側型 (lateral type), 内包より内側に出血があつたものを内 側型（mesial type）としている。著者は金谷らの診断 法2゙準拠して研究対象を脳出血の型に分類した。な お，内側型は視床を中心としておこるものであるが，そ の診断が容易でない場合が多く，症例も少ないために， この型を除外した。

外側型と内側型をあわせもつたものを混 合型 (combined type）上言う場合もある。金谷ら ${ }^{2}$ は混合型外 側型が視床および視床下部にまで抢よんだものとしてい る。すなわち，混合型は外側型上りその病坚が大きいも のと考えられる。

媨血管写所見による部位診断について，金谷ら゙㨫 出血症例に扔ける術前血腫局在部位の鑑別診断法を発表 している。すなおち，

(1) sylvian group の内側偏位は前大脳動脈の偏位の有 無関することなく，全例外側型である.

(2) 前大脳動脈のみ偏位，あるいはこれと中大脑動脈の 外側偏位を示すものの多くは外側型である.

(3) 中大脑動脈のみ外側に偏位を示すものの過半数は内 側型と外側型にわたる混合型である

(4) 線状体動脈については，脳底に対して直立あるいは 内側に偏位するもののほとんど大部分は外側型で，側 面像の前脈絡動脈の下方偏位をするものの65\%は混合 型であると言つている。

小野寺 ${ }^{57}$ は高血圧性脳出血の血腫型の鑑別につ、てて信

頼度の高い所見として次のよらにいっている。

(1) 脑出血時の血圧が $180 \mathrm{mmHg}$ 以下のものには外側型 が多く, $180 \mathrm{mmHg}$ 以上のものには混合型が多い

(2) 意識障害の程度は重要で，昏睡などの高度の意識障 害を示すものは混合型に多く，外側型では比較的半昏 睡，昏迷程度に止まるものが多いまた 3 時間以内に 高度意識障害に楩いるものは混合型に多い。

(3) 噇孔反応で注外側型は比較的正常を示すものが多 く，混合型では反応がないものが多い

(4) 共同偏視は外側型に多く, その他四肢の運動麻疩,
表 1 障害部位の診断し得た50例の内訳 脳出血症例

\begin{tabular}{c|c|c}
\hline \multirow{2}{*}{ 外 側 型 } & 病 側 & 例 数 \\
\hline \multirow{2}{*}{ 混 } & 合 型 & 13 \\
\hline & 左 & 17 \\
\hline & 左 & 4 \\
\hline
\end{tabular}

脳硬塞应例

\begin{tabular}{c|c|c}
\hline 閍塞部位 & 病 側 & 例 数 \\
\hline 内頸動脈 & 右 & 2 \\
\hline \multirow{2}{*}{ 中大脳動脈 } & 右 & 2 \\
\hline & 左 & 4 \\
\hline 前大脑動脈 & 右 & 1 \\
\hline & 左 & 1 \\
\hline
\end{tabular}

樑部反射㧍よび病的反射なども血腫部位の判定に指標 となり得る。 といっている.

脑硬塞は細小動脈の閉塞でもおこり得るが，診断困難 であるので脳血管写により診断し得た脳主幹動脈の閉塞 例のみを選んだ。

以上の基淮により，著者が研究対象を分類した 143 例 中，障害部位が確定した50例は表1のごとくである。

$$
\text { III 症例 }
$$

症例 1,55 歳, 男

家族歴：特記すべきものなし。

既往歴：昭和 47 年 7 月, 健康診断にて高血圧上慢性腎炎 を指摘された。

現病歴：昭和49年8月14日朝食瑷，急に左上肢，下肢が 動かなくなつたが意識障害はなかった。

入院時現症：意識は清明，血圧166/90，うつ血乳頭はな かつた，左顔面神経麻㾇．舌は左に偏位し，左不完全片 麻瘦を認めた，枟Myer 反射は陽性，腱反射は左が右に 比ベ充進していた，左バビンスキ一陽性．䯣液検查では 初生 $170 \mathrm{mmH}_{2} \mathrm{O}$, 水様透明, 緿登白 $60 \mathrm{mg} / \mathrm{dl}$, 糖 $60 \mathrm{mg} / \mathrm{dl}$, 細胞は $2 / 3$.

檤血管写所見（図1）：正面像㧍上び側面像にて在内频 動脈 C-5にて閉塞を認めた。

脳シンチグラム（図2）：右中大㮸動脈領域に広範な陽 

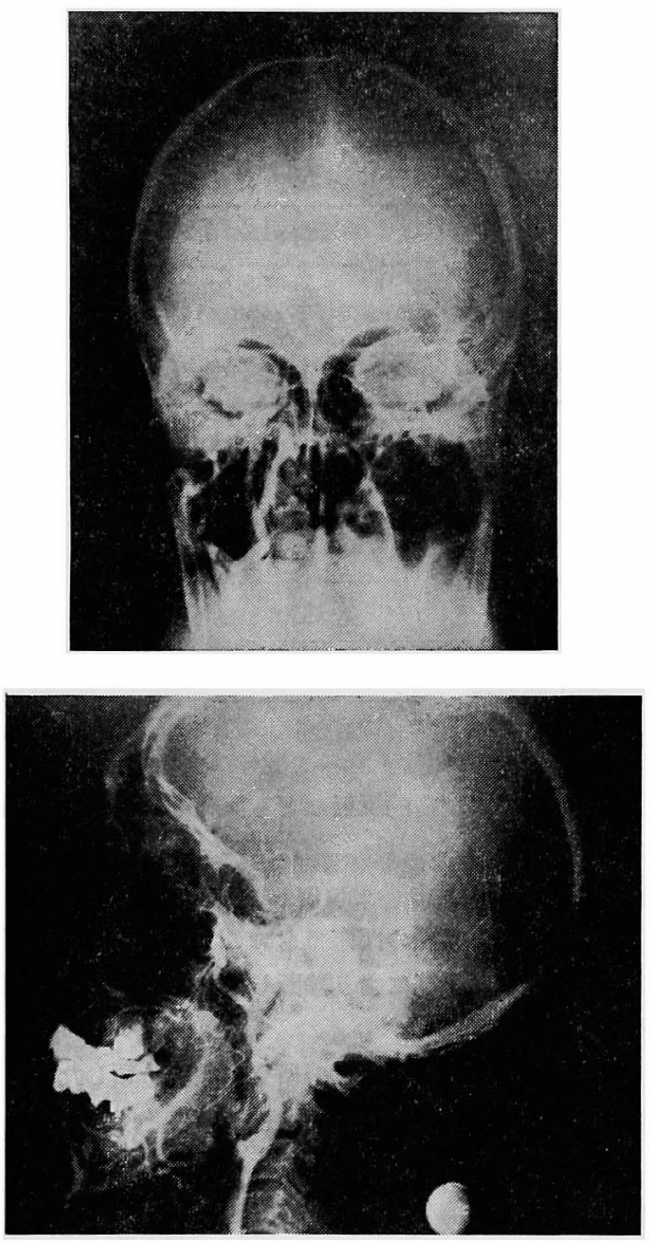

図 1 症例 1 の右頸動脈撮影にて内頸動脈閉塞 を認む

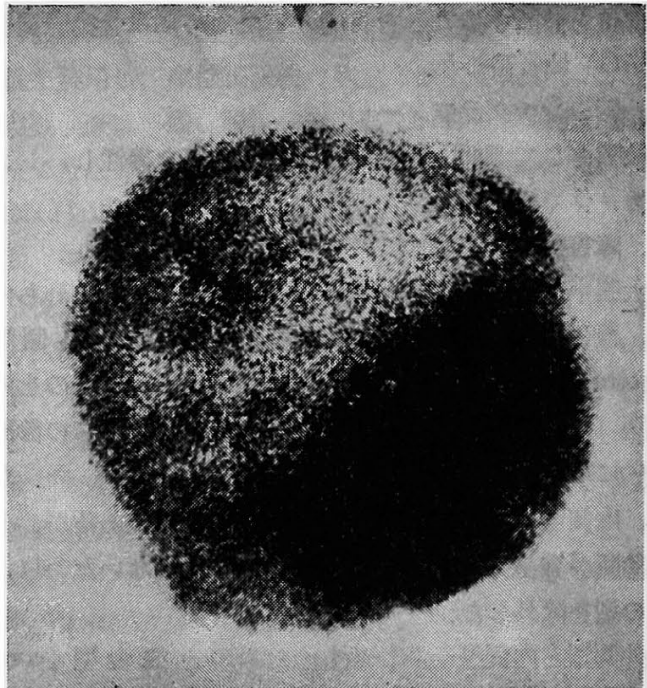

図 2 症例 1 の脳シンチグラムにて, 右中大脳 動脈領域に陽性の集積像を認む

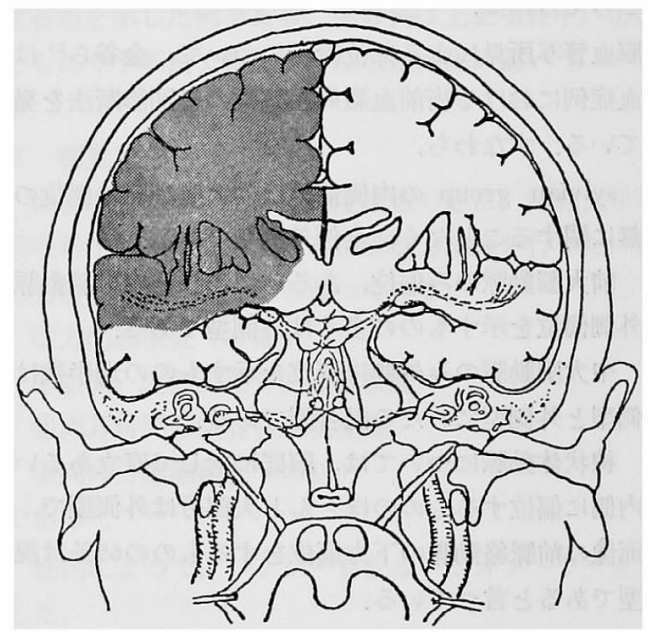

図 3 症例 1 の推定される障害部位

た. 温度眼振検査は正常であつた.

視運動性眼振検査 (図 5) では左 OKP の解発不良, 眼振緩徐相速度の上昇は両 OKP とも障害されていた が，左 OKP は著しかつた，すなわち，OKP にて高度 の左右差が認められた。

聴覚検查 (図 6) では, 純音聴力検査にて平均聴力損 失は両側とも約 $19 \mathrm{~dB}$ で山型を示していた. 特殊聴力 検査では, 方向感, 左歪語音明瞭度がやや不良, 両耳分 た. 頭位変換眼振検査では図のごとく水平性眼振を認め 


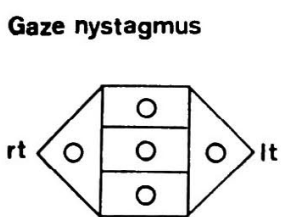

with Frenzel-Glasses

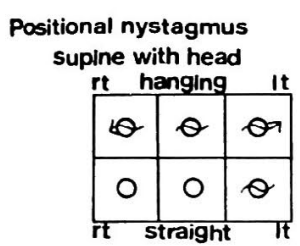

Positioning nystagmus

supine with head

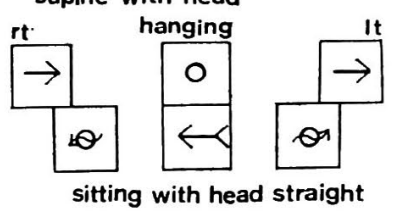

図 4 症例 1 の眼振所見
離能検査では左耳が０\%と著しく低くかつた。

症例 2.26 歳, 男

家族歴・既往歷：特記すべきものなし．

現病歴：昭和48年 7 月 29 日, 朝食事中に頭痛を訴え, そ の後意識障害が 3 日間持続した. 血圧 $240 / 140$, 右上肢, 下肢が動かず, 㹩度の言語障害があつた。

入院時現症：意識は清明, 血圧 $140 / 80$, 瞳孔は左右不同 （右>左）であつたが, 対光反射は正常であつた. 右半 身に知覚低下および右下完全片麻㽻を認めた。腱反射は 右が左に比べ亢進しており，右バビンスキー陽性であつ た．柽度の運動性失語症を認めた。

脳血管写所見 (図7)：正面像にて, 前大絲動脈の偏位 はないが，中大脳動脈の外側偏位および線状体動脈の内 側偏位を認めた。側面像にて中大脳動脈の挙上がみられ た．以上の所見から左外側型の出血が推定された．推定 される障害部位を図 8 に示寸.

耳鼻咽喉科所見：両側鼓膜, 鼻内, 咽喉頭所見に異常 を認めない

眼振検查（図 9) では, 注視眼振は左右注視方向性に, 頭位眼振は方向交代性上向性眼振を 認めた．頭位変換 眼振は眼振様運動または不定の眼球運動がみられた．温

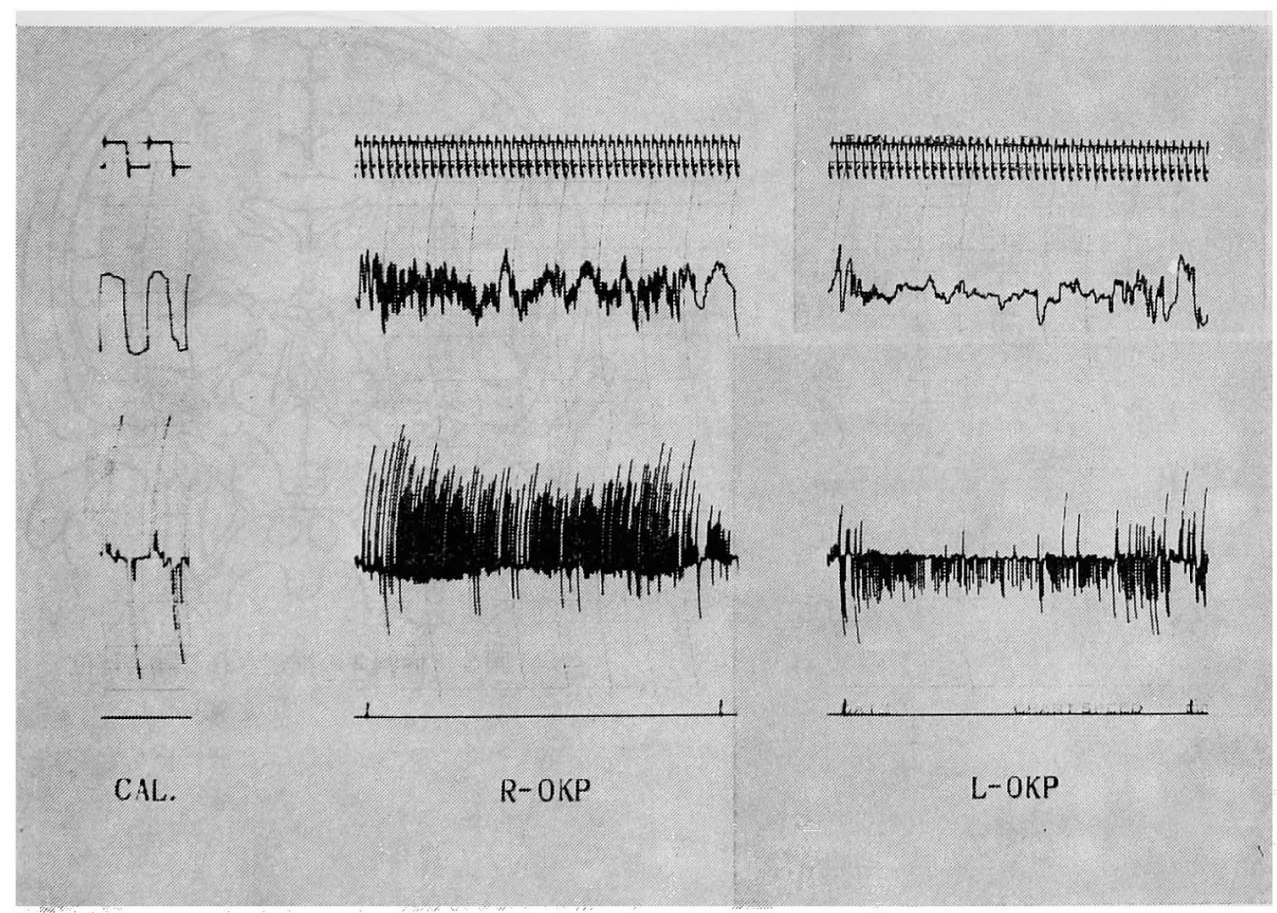

図 5 症例 1 の OKP 所見（較正は $10^{\circ}$ ) 
オージオグラム

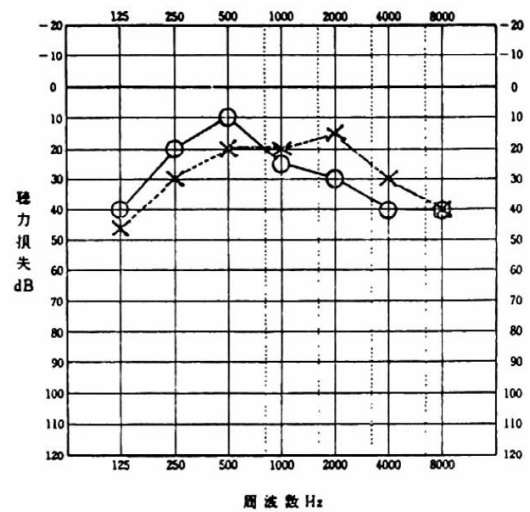

図6 症例 1 の聴覚検査
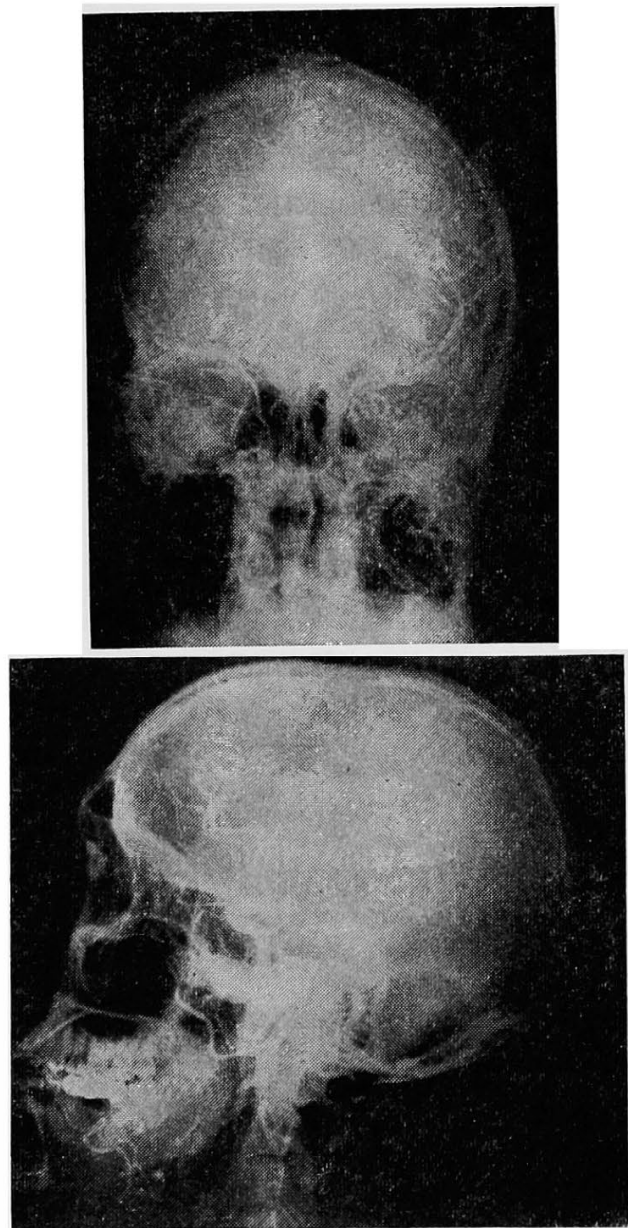

図 7 症例 2 の左頸動脈撮影
部音并別能右 $95 \%$ 左 $80 \%$

特殊恥力検查

1. 方向感 $10 / 21$

2. 正語音明瞅度 右 $65 \%$ 左 $30 \%$

3. 而耳合成能 $75 \%$

4. 两耳分部能右 $100 \%$ 左 $0 \%$

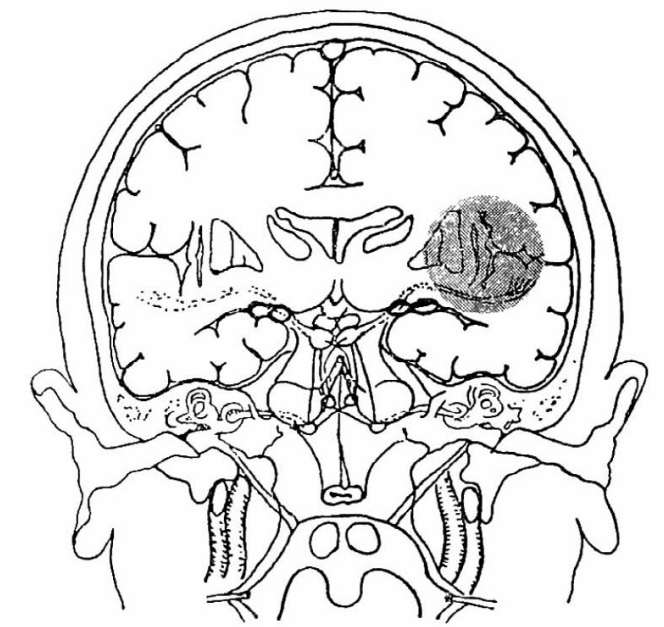

図 8 症例 2 の推定される障害部位 
Gaze nystagmus

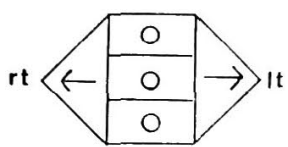

Positional nystagmus

supine with head

$$
\begin{array}{|c|c|c|}
\hline 0 & 0 & \leftarrow \\
\hline \rightarrow & \diamond & \leftarrow \\
\hline
\end{array}
$$

Positioning nystagmus

supine with head

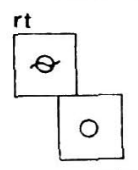

hanging
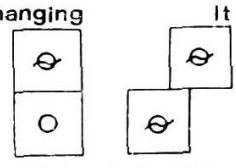

sitting with head straight

図 9 症例 2 の眼振所見 with Frenzel-Glasses

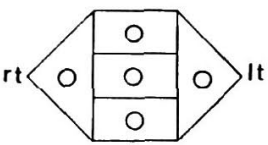

$\mathrm{O}$

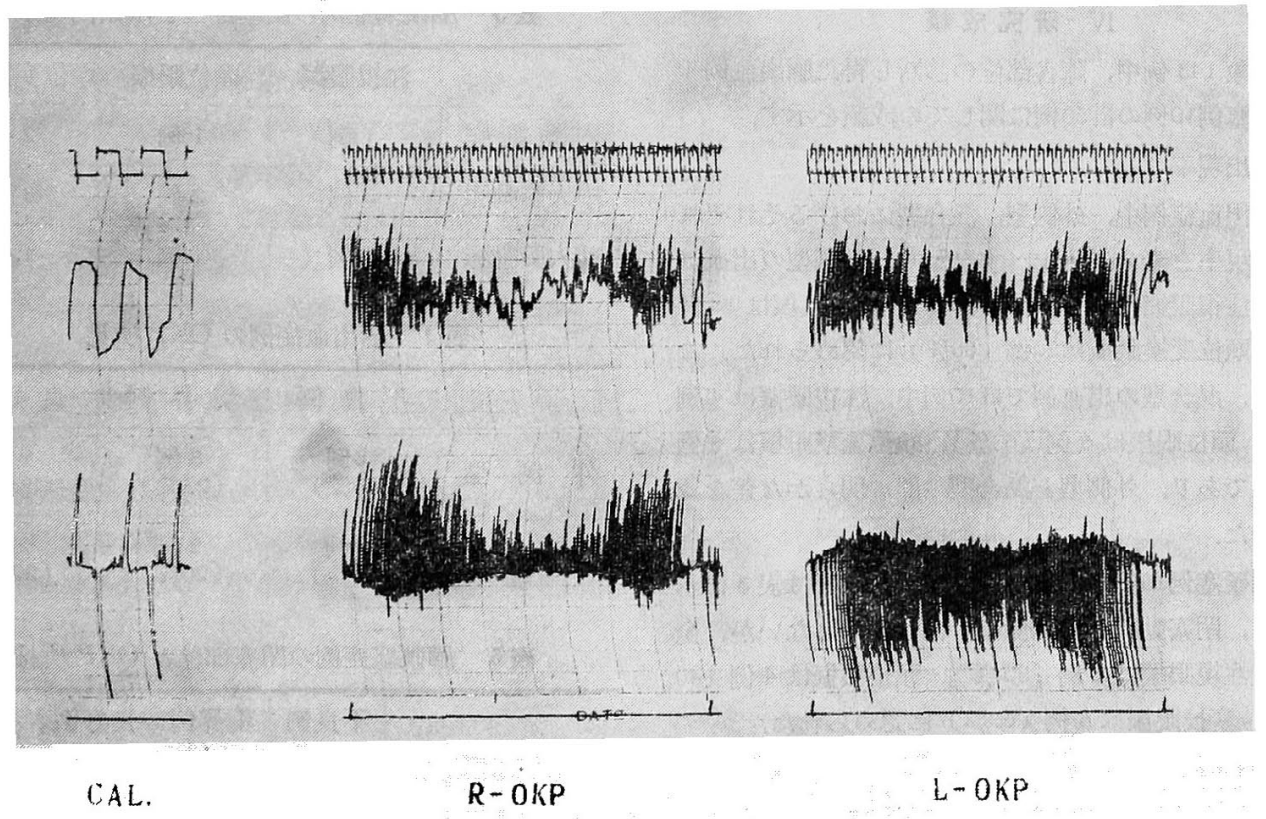

図10 症例 2 の OKP 所胃（較正は $10^{\circ}$ ) 


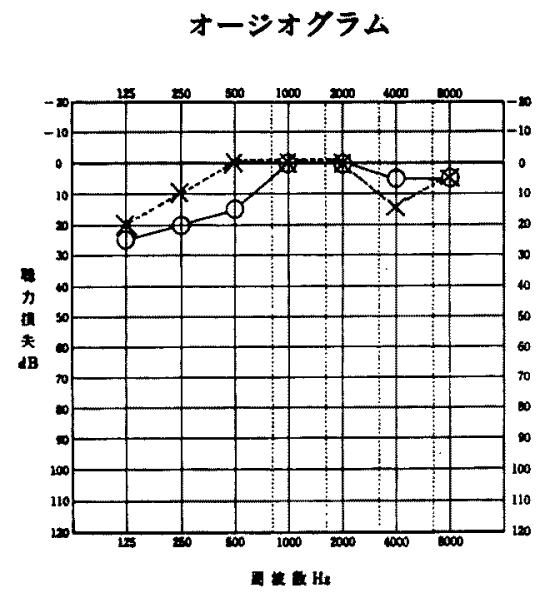

解音别能右 $65 \%$ 左 $90 \%$

図11 症例 20 聴覚検查

度眼振検查では正常であつた。

視運動性眼振検查（図10）では右 OKP の解発不良， 眼振緩徐相速度の上昇は左右とむやや障害された。蓑な わち，OKPにて明らかな左右差加認められた。

聴覚檢查 (図11) では，純音聴力検查で大略正常であ るが，右耳の語音弁別能注下し，右耳の分䧺能は著し

く低下していた。

\section{IV 研究 成績}

研究対象 143 例中，障害部位の診断し得た脳出血例 40 例, 脳硬塞例10例の計50例に関しての成績を示す。

\section{1. 眼振出現率}

（1）眇出血症例中，外側型，混合型におけるそれそれ の眼振出現率を表 2 に示す。すなわち，外側型の出血例 30 例中の注視眼振は 12 例 $(42 \%)$ ，頭位眼振は 18 例 $(58 \%)$, 頭位変換眼振江20例 $(65 \%)$ に認められた。 こ れに対し，混合型の出血例では10例中，注視眼振は 4 例 $(40 \%)$, 頭位眼振は 6 例 $(60 \%)$, 頭位変換眼振は 6 例 (60\%) であり，外側型と混合型の間に明らかな差を認 わなかつた。

(2) 脑硬塞例10例の閉塞部位と眼振出現率は表 3 に示 すごとく，閉塞動脈との関係は，はつきりしないが，全 体上して注視眼振は 5 例 $(50 \%)$ ，頭位眼振は 4 例 (40 $\%)$ ，頭位変換眼振は6例 $(60 \%)$ に認められた。

\section{OKP 所見}

(1) 脳出血症例に扎いて，表 4 に示すごとく，外側型 では不良例が13例 (43\%)，混合型では6例 $(60 \%)$ で あるが，对象数に差があるために明確な判定は問題があ
表 2 腷出血症例の眼振出現率

\begin{tabular}{c|c|c|c}
\hline & 注視眼振 & 頭位眼振 & 頭位変換眼振 \\
\hline 外 側 型 & $\begin{array}{c}12 \text { 例 } \\
(42 \%)\end{array}$ & $\begin{array}{c}18 \text { 例 } \\
(58 \%)\end{array}$ & $\begin{array}{c}20 \text { 例 } \\
(65 \%)\end{array}$ \\
\hline 混 合 型 & $\begin{array}{c}4 \text { 例 } \\
(40 \%)\end{array}$ & $\begin{array}{c}6 \text { 例 } \\
(60 \%)\end{array}$ & $\begin{array}{c}6 \text { 例 } \\
(60 \%)\end{array}$
\end{tabular}

表 3 脱硬塞䆙例の閉塞部位と眼振出現率

\begin{tabular}{c|c|c|c}
\hline & 注視眼振 & 頭位眼振 & 頭位変換眼振 \\
\hline 内頸動 脈 & 1 例 & 1 例 & 2 例 \\
\hline 中大脳動脈 & 3 例 & 2 例 & 3 例 \\
\hline 前大脳動脈 & 1 例 & 1 例 & 1 例
\end{tabular}

表 4 脑出血症例の OKP 所見

\begin{tabular}{c|c|c|c}
\hline & 不良例 & 境界例 & 良好例 \\
\hline 外 側 型 & $\begin{array}{c}13 \text { 例 } \\
(43 \%)\end{array}$ & $\begin{array}{c}8 \text { 例 } \\
(27 \%)\end{array}$ & $\begin{array}{c}9 \text { 例 } \\
(30 \%)\end{array}$ \\
\hline 混 合 型 & $\begin{array}{c}6 \text { 例 } \\
(60 \%)\end{array}$ & $\begin{array}{c}2 \text { 例 } \\
(20 \%)\end{array}$ & $\begin{array}{c}2 \text { 例 } \\
(20 \%)\end{array}$
\end{tabular}

表 5 这硬塞症例の閉塞部位とOKP 所見

\begin{tabular}{c|c|c|c|c}
\hline & 不良例 & 境界例 & 良好例 & 不能例 \\
\hline 内頸 動 脈 & 2 例 & 0 & $\bigcirc$ & $\bigcirc$ \\
\hline 中大脙動脈 & 4 例 & $\bigcirc$ & $\bigcirc$ & 2 例 \\
\hline 前大脳動脈 & 2 例 & $\bigcirc$ & $\bigcirc$ & $\bigcirc$
\end{tabular}


表 6 脳出血症例の障害部位上両耳分﨎能検查

\begin{tabular}{c|c|c|c|c}
\hline & 異常例 & 境界例 & 正常例 & 不能例 \\
\hline 外 側 型 & $\begin{array}{c}16 \text { 例 } \\
(53 \%)\end{array}$ & $\begin{array}{c}10 \text { 例 } \\
(30 \%)\end{array}$ & $\begin{array}{c}4 \text { 例 } \\
(13 \%)\end{array}$ & 0 \\
\hline 混 合 型 & $\begin{array}{c}2 \text { 例 } \\
(40 \%)\end{array}$ & $\begin{array}{c}2 \text { 例 } \\
(20 \%)\end{array}$ & $\begin{array}{c}2 \text { 例 } \\
(20 \%)\end{array}$ & $\begin{array}{c}2 \text { 例 } \\
(20 \%)\end{array}$
\end{tabular}

表 7 这硬塞症例の閉塞部位と両耳分離能検查

\begin{tabular}{c|c|c|c|c}
\hline & 異常例 & 境界例 & 正常例 & 不能例 \\
\hline 内頸 動 脈 & 1 例 & $\bigcirc$ & 0 & 1 例 \\
\hline 中大腷動脈 & 4 例 & 0 & 0 & 2 例 \\
\hline 前大腷動脈 & 1 例 & $\bigcirc$ & 1 例 & $\bigcirc$
\end{tabular}

表 8 脳卒中患者 143 例の眼振出現率

\begin{tabular}{|c|c|c|}
\hline 注 視 眼 振 & 頭 位 眼 振 & 頭位变換眼振 \\
\hline $\begin{aligned} 40 & \% \\
(57 & \text { 例) }\end{aligned}$ & $\begin{aligned} 58 & \% \\
(82 & \text { 例 })\end{aligned}$ & $\begin{array}{cc}67 & \% \\
(95 & \text { 例) }\end{array}$ \\
\hline
\end{tabular}

るが，混合型の OKP は外側型に比べ不良例が多い傾向 にある。

（2）脳硬塞症例においては，表 5 に示すごとく，2 例 の不能例を除き，全例が不良を示した。

3. 聴覚検查 (両耳分離能検查)

(1) 脳出血症例では表6に示すごとく，異常例は外側 型で16例 (53\%)，混合型で 4 例 (40\%) と明らかな差 を認めないが，両型とも約50\%纪異常を示した。

(2) 脑硬塞症例において浪 7 の示すごとく, 閉塞部 位との関係は明らかではないが，不能例 3 例招よび正常 例 1 例を除き，他の6 例恃全例が異常を示し，しかも健 側耳が不良であった。

次に, 脳卒中患者 143 例の神経耳科学的所見を表に示 ఫ.

\section{1. 眼振出現率 (表 8)}

注視眼振 $40 \%$ (57例), 頭位眼振 $58 \%$ (82例), 頭位変 換眼振 $67 \%$ (95例) で，腷卒中患者の約 $55 \%$ に何らかの 眼振を認めた。

\section{2. 視運動性眼振検查}

脑卒中患者 143 例の OKP 所見を表 9 亿示す.

不良例社 62\%（89例），境界例 16\%（23例）であり， 全例の約 $60 \%$ 近くには明らかに異常が諗められ，それら は注全例が健側 (片麻渾側) 向きの OKP が不良であ つた。
表 9 脳卒中㭧者 143 例の OKP 所見

\begin{tabular}{|c|c|c|}
\hline 不良 例 & 境 界 例 & 泉 好 例 \\
\hline $\begin{aligned} 62 & \% \\
(89 & \text { 例 })\end{aligned}$ & $\begin{aligned} 16 & \% \\
(23 & \text { 例 })\end{aligned}$ & $\begin{array}{cl}22 & \% \\
(31 & \text { 例 })\end{array}$ \\
\hline
\end{tabular}

表10 䏚卒中患者 143 例の両耳分離能検查

\begin{tabular}{|c|c|c|c|}
\hline 異常例 & 境界例 & 正常 例 & 不能 例 \\
\hline $\begin{aligned} 45 & \% \\
(64 & \text { 例) }\end{aligned}$ & $\begin{array}{c}23 \% \\
(33\end{array}$ & $\begin{aligned} 19 & \% \\
(27 & \text { 例 })\end{aligned}$ & $\begin{array}{r}13 \% \\
(19 \text { 例 })\end{array}$ \\
\hline
\end{tabular}

\section{3. 聴覚検查 (両耳分離能検查)}

両耳分離能検查の成績を表10 亿示す。143 例中, 検查 不能例は19例であり，異常值を示したのは50\%近くに認 められた。

\section{$\mathrm{V}$ 考按}

I. 前庭平衡系について

(1) 脳卒中症例に打ける眼振出現

腷卒中症例の異常眼球運動の一つである共同偏視は昔 から病巣部位の診断に役立つと言われてきた。龟山占に よると，脳血管障害例の異常眼球運動は病巣診断扝よび 予後の判定に重要であり, 大这半球の外側型障害では病 巣と同側の共同偏視が生し，内側型障害では下方共同偏 視を生ずることが少なくないと述べている。

眼振出現の原因が末梢の耳石器拉よび三半規管から中 枢の脑幹，小脑を含む天幕下に起因すると考えられてい る限り，天幕上の原病巣と眼振所見を直接結びつけるの はあまり意味がないと思われる。

しかし，第 2 症例の脳出血の外侧型障害例では, 左右 注視方向性の眼振を認め, 頭位眼振では方向交代性上向 性眼振を認めた。この症例では, 純音聴力検查, 温度眼 振検查上り内耳障害は否定された。

その他の腷出血症例の眼振出現率注，外側型では注視 眼振 $42 \%$, 頭位眼振 $58 \%$, 頭位変換眼振 $65 \%$ であり, 混 合型で法注視眼振 $40 \%$ ，頭位眼振 $60 \%$ ，頭位変换眼振 60 \%であった，すなわち，脳出血例でも高頻度に眼振を認 めたが，外側型と混合型の間に明らかな差を認めなかつ た。

脑主幹動脈閉塞による脳硬塞症例でも, 注視眼振 50 $\%$, 頭位眼振 $40 \%$, 頭位変換眼振 $60 \%$ と高頻度に眼振圭 認めた。しかし，閉塞部位と眼振出現に関して相関は認 められなかった。

以前から、メニエール病に代表される末梢障害では， 振幅の小さい，頻度の大きい眼振が認められ，脱腫瘒な 
どの中枢性障害では振幅の大きい，頻度の小さい眼振が 出現しやすいことは知られていた。

德堌汭注, 水平性眼振の出やすい力府について報告し ている、それによると，脳幹前部老境としてそれより上 方乱よび天幕上障慧では水平性眼振は㭧侽向きに出や寸 く,脳幹中部以下，すなわら橋，前部延髄抢よび小脳の 天幕下疾㭧，さらに前庭神経，末梢迷路疾患では健側入 眼振が出やすいと述べている。

譄卒中症例でも脳出血は脑腫瘍のごとく space occupying lesion と考えられるため，出現した水平性眼振に ついては，その方向，振幅，頻度などを問題とすべきで あるが，脳出血患者40例中に諗められた水平性眼振の力 向に関しては一定の傾问寺さなかつた。

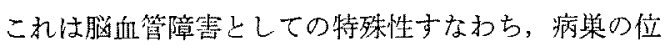
置, 同じ衈管が開塞しても病変の程度はさまざまである などの他に，検楂時期などの経時的な点む十分考感に入 れなければならない，その他の要索しして，注視眼振と 非注視眼振では，その出現機楧に関して異なり，注視眼 振では注視機能を主とした眼連動秀を中心とする中枢機 構の存在が大きい

こ机に対して, 非注視眼振では小脑系, 「系, 眼運動 系が関与するが，その主体は前庭系でありこの雨者で その背景がやや異なる7

藤畸ら し，注入した側を下にすると上向性の側頭位眼振を認 め，両側頸部交感神経切断家鬼において両側頭位で下问 性眼振を認的た奏験をもとに，側頭位眼振を示家鬼の 譄血流を測定した，その奏験によると，上向性頭位眼振 は上位側の血流増加，あるいは下位側の血流減少により 生じ，下向性頭位眼振はその逆であると述心゙ている。す なわら, 方向交代性頍位眼振の出現に関し, 血流の变化 から説明している。

脳卒中症例では出血や硬塞による局所の媨循環障害に より脳機能障害在きたすことはすでに明らかである。そ れに伴ない脳主幹動脈の媨循謤も高度に低下し，しかも それは椎骨動脈に著明であると言われているするとのた

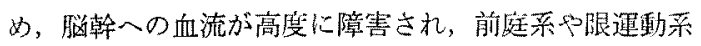
の障害を起こすことは十分に考えられる，しかし，檤卒 中症例では脳血管障害の特殊性として，病隼の大きさや 位置，血管閉塞の部位などにより胹循環不全の程度むさ まざまであるため，著者の症例でむ出現した眼振が一定 の傾向を示さなかつたむのと考えられた。

(2) 天幕上障害と視運動性眼振䄼查
視瓷動性眼振険查加臨床検查法として，紹介されたの は，1920年に Bárány が半盲症の診断に用いてからであ る。その後，視逨動性眼振検查はもつばら大脳障害部位 との関係について注目された。1949年 Cogan-Loeb ら ${ }^{102}$ は90名の天幕上障害例について，58例に病巣側への optokinetic response の異常を認めたので，その障害部 位との關連性について報告した。

optokinetic response の異常は大脙のどの部位でも認 められたが，最も高頻度に認められたのは，後頭葉， 頍頂後頭部，側頭葉，前頭葉の順であつた。そこで，

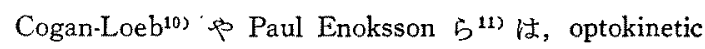
response は大脳半球病獘の局在診断に意義のあること を主張し，畝幹障恝の診断学的意義に関してはむしろ否 定的ですな。

しかし, 近年の研究では, optokinetic response の異 常注媨幹障害によると考えられておりり12)，大脑半球障 需より脳幹障害心崄断学的意義があると考えられてい b.

脳卒中急性期を過ぎた症例の媨幹障害は，一般神経学 的諸検查からは䛦断しがたい。しかし，視運動性眼振検 查では異常を呈することが多く，脉出血症例では外側型 の障害に比べ混合型の障菫すなわち，内包を中心に出血 が視床におよぶ症例については OKP の不良例が多、傾 问にあつた。

許ら ${ }^{13)}$ は，大脳半球に㧍ける視野の障害を有する症例 について，視運動性眼振検查と聴覚検查上り報告し，天 草上の内・外側膝状体に障害がおよぶと, 視運動性眼振 検査にて障害の反奶側の OKP がより障書されると報告 している。すなわら，天幕上の内・外側膝状体加ら两侧 の視運動性眼振に対する神経支配が考えられると結論し ている。

ゆえに，脳出血の混合型は外側型の障害部位をも含 め，障害部位が大きいため，内：外側㯟状体が直接的な 影䭗索受けやすい，乙のために不良例方多いと考える。 OKP 所見の判定は ${ }^{712}$, (1)眼振緩徐相速度の上昇, (2)視湩動性刺激に対する反応の程度, (3)optokinetic fusion limit の低下の有無, (4)左右差, の4 項目加ら, 不 良例，境界例，良好例に分けた。不良例と境界例は共に 上記項目中の(1)，(2)，(3)の障慧も含み，しか子不良例仕 明らかな左右差を有し，境界例は左右差を認めがたいも のである。このように OKP 所見を 3 群に分けた理由 は，膊卒中患者 143 例の OKP 所見が程度の差はあつて も, 大略 3 群に分類され得たこと, および天幕上障害例 
では一般に，健側に向から視運動性眼振が障害されるこ とに基ゔいている，今回の成績でも左右差の認められた 症例は全例が健側に向かう視運動性眼振が障害されてい た.

㗖主幹動胍閉塞例を扱つた脑硬塞症例では，はとんど が OKP 所見の不良例であり，境界例や良好性恃認めら れなかった。 寸なかち，不良例か不能例であり，不能例 では一般神経学的検查より脳幹障害が認められ，しかも 重症例であつた。

閉塞性媨血管障害において，閉塞が必ずしも脑硬塞を おこさないことはすでに明らかである16153 すなおち，

䏚動脈造影上闒塞を認めても，その動脈の支配頒域と害 際の脑硬塞の抎がりが一致するとは限らない，その理由 は，脳内血管はその走行に括いて多くの variation があ り，Willis 動脈輪などにみられるような副側血行路に

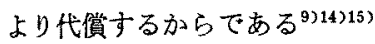

Torvik らは ${ }^{16)} ， 54$ 例の頸動脈開塞の剖検から，その $78 \%$ に脑硬塞を認め，臨床症状を呈したものは79\%であ ったと報告している，そして，頸動脈閉塞における病笨 の搪がりを 4 つに分類し，急速に発症したものでは， total infarct が多いと述べている.

著者の症例では, 内頸動脈閉塞 2 例および前大脳動脈 閉塞 2 例ともに OKP 所見が不良であるが, 中大脳動脈 閉塞 6 例飞おいては不良例が 4 例と不能例が 2 例と同し 中大脳動脈の起始部の閉塞でありながら差が認められ た。 すなわち，同じ動脈が閉塞しているにもかかわら ず, 視運動性眼振検查では不良例から不能例むでその程 度は種々であり，これは，その動脈の支配領域之実際の 訤硬塞の搪がりが一致するとは限らないことをある程度 示していると考えられる。

視運動性眼振は注視機能を中心に考えると, 中心简 眼振 (foveal nystagmus) 々網膜型眼振 (retinal nystagmus）の両成分からなりたつている。視運動性眼振 の解発には，一つの物体を明瞭に見るために，その映像 を網膜中心简にとらえ，注視しながら追跡する随従運動 (pursuit movement) からなる随意眼球運動が中心とな り，ドラムの回転が低速度の場合は中心䂏型眼振が主体 である ${ }^{17219}$ ，しかし，眼球運動の支配中枢は非常に複雑 で，不明な点がかなり多い，側方共同運動の皮質中枢は 主として，前頭葉と後頭葉にあり，前頭葉では第 2 前頭 回の後部，すなわち，Brodmann 8 野に存在し，㣪頭葉 では限局されたある部分のみが関与するのではないと落 えられる。前頭葉には意志に基つく眼球の随意運動の中 枢があり，impulse 在脑幹に送り，眼球運動を引き起こ す. 後頭葉は視敩機能と密接な関倸があり，動く物体を 眼で追ら随彷運動户視野の周辺儿ある物体を網膜中心窝 にとらえようとする随意固視運動空中心とする眼球運動 に関与している，以前より，前頭葉と後頭葉の閒に連絡 があることは知られて㧍り，前頭葉皮犋中枢は同側およ び反対側の両後頭葉に連絡線維を送つていると考えられ ている ${ }^{19}$

視運動性眼振における眼振緩徐相は眼前の動く線状を 注視し，追跡する相にあたり，それにはこの眼球運動の 動きと反刘側の後頭莱が関与している. 眼球の水平性運 動についての後頭葉からの下行性系路は, 脳幹網様体に 入り，そのほとんどの線維は動眼神経核と滑車神経核の レベルで交叉し，橋部脳幹の pontine gaze center に入 ると考えられている。

これに対し，眼振急速相はその方向上反対側の前頭葉 が関与している。根球の水平性運動については，下行性 線維泊質中の放線状冠の中を通り，錐体路の一部とな り，脳幹神経核 (basal ganglia) を通り，動眼神経核の レベルで交叉したあと反対側の橋部脳幹網様体の等正中 部 paramedian pontine reticular formation (PPRF) $K$ 入ると考えられている(図12) 20321

小松崎 ${ }^{222}$ は眼振急速相の解発および眼球共同注視機能 に関し，PPRF が重要な役割を果たして㭁り，橋部脳幹 障害の謋断学的意義について述べている.しかし，PPRF の障害のみならず，前頭葉から PPRF に至るまでの経 路に障害があれば大䏼半球でも譄幹でも同じような障害 が起り得ると考える。

前頭葉と㣪頭葉の連絡は頭頁葉の深部にあるといるれ ている pathways による.この pathways により前顓葉 は後頭葉からの impulse を受け，次の線を固視するた 的視運動性眼振湌查にて，街動性運動 (saccadic movement）をすると考えられる。そのため，例えば左頭頂 葉に障害のある場合，右に向かう視運動性眼振の反忘沬 急速相で著明に障害される（図13）、才なっち，天幕上 障害では前頭葉と後頭莱を中心とする眼運動系が障害さ れると視運動性刺激に対する眼振急速相の反応が障害さ れると考えられる。ゆえに，天葧上に障害の多い慆卒中 症例に対しても視運動性眼振検查結果をパターンとして 判定する限りにおいては，障害部位判定，重症度の判定 にもある程度意義があると考えられる。

しかし，脳卒中症例では大檤半球に障害のあるものが 多く、眼運動系が大䏚レンルで障害されていることの他 

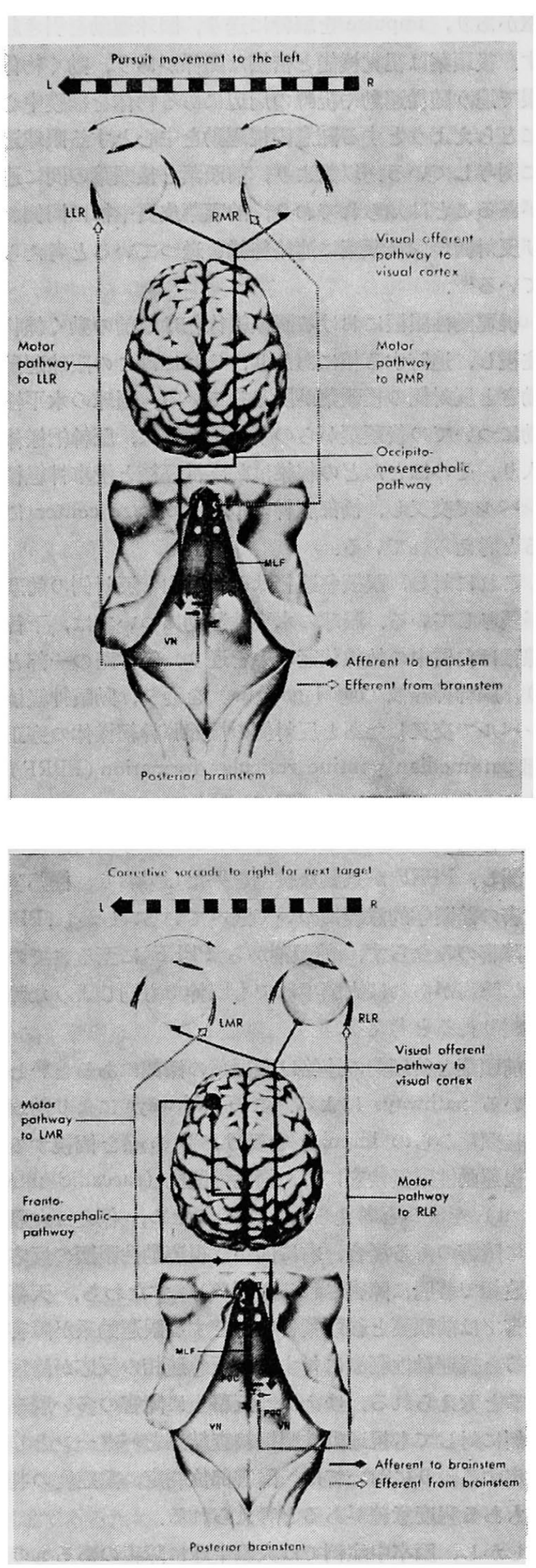

図12 視運動性眼振の緩徐相と急速相 ${ }^{20}$

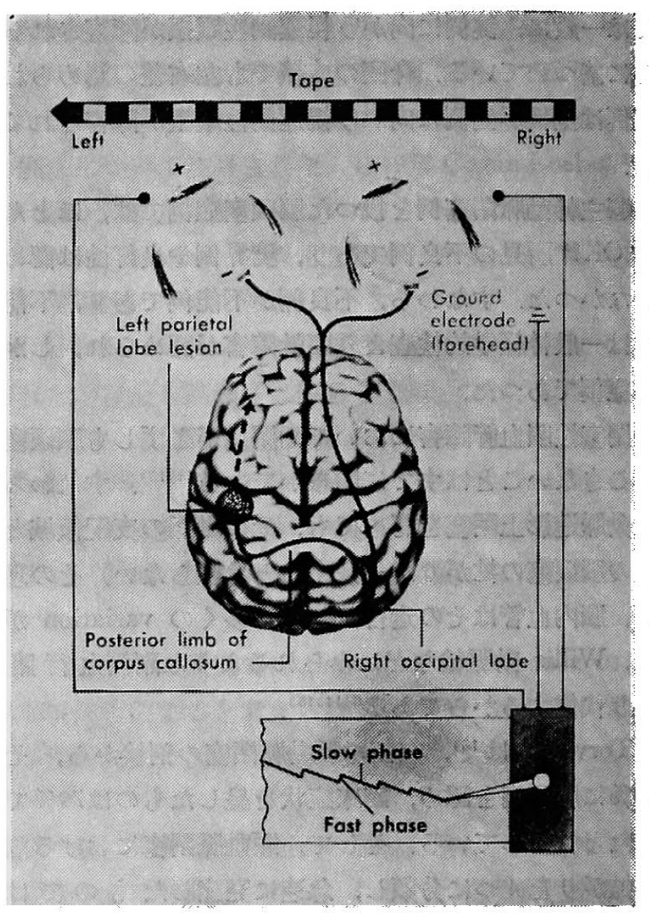

図13頭頂葉障害におりる視運動性眼振20)

に，脳幹を中心とした脑幹網様体や小脳レベルでの眼運 動系の障害がおこりらるといらことはいらまでもない． その理由として, 脳卒中急性期において, その病変が天 幕上に限局する小さなものでも, 局所障害のために脑浮 尰を生じ, 脳圧は亢進するとともに腷機能障害を起こ す.この一連の病態は何らかの影響が脳卒中患者の脳幹 に加えられることを示唆しているからである.

II. 聴覚系からの診断学的意義

恥觉生理や病理学的研究の進歩により, 中耳, 内耳よ り聴中枢に至る聴覚伝導路が次第に明らかになってきた ので, 中枢神経障害に対し, 聴覚検査による病巣診断は ある程度まで可能となってきた. 聴賞伝導路は蝸牛を発 してから延髄の背側, 腹側の両核で一部左右交叉して上 オリーブ核に行き，外側毛帯から下丘に入り，内側膝状 体に終る．ここでニューロンを変えていわゆる聴放線を 形成し，レンズ核の下後方を放射状線維が束となり通過 し, 側頭葉の横側頭回すなわち, Heschl 回に入る ${ }^{28)}$. いずれの耳から入つた音も脳幹を通り伝達されるが，反 対側の伝導路作用がやや優位であるとされている. 聴覚 伝導路は最低 4 個, 最高 7 個のニューロンを経て脳皮質 に達している。 
大媨皮質，皮畝下，基底核，内包など天幕上に障害の 多い檤卒中症例では，内側膝状体加ら側頭葉のシルビー 回の深部に存在する Heschl 回までの経路は解剖学的に る障害を受计やすいと考えられるため，脳卒中発作㭙に 傍覚の異常を引き起こすことは十分あり得る。

後迷路性難聴の診断に際し,

(1) 方向感検査は両耳に入る音の強さと時間の差に上 り，頭蓋内での音像の偏位を調べる検査である。この検 查は譄幹交叉部より上方の障害で異常を示しやすく，音 像が偏位する場合は同側の脑幹または反対側の大脳に障

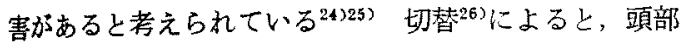
外偤, 膇卒中による片麻㾝症例, 家族性難聴, 再側低音

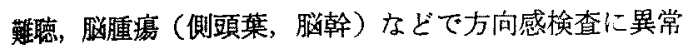
を認めると述べている。

(2) 歪語音明燃度検查は検查語音に歪を加えることに 上り無歪語音検査で注判定しがたい場合にも異常を想め ることができる，一般に純音聴力損失域值の上界により 語音明膫度が悪くなる傾向が多いが，域值が正常にもか 加らず, 明睹度の悪、場合は後迷路性難聴を推定し得 る.

(3) 両耳合成能険查住後迷路性難㯖のうちでも，脑幹 交叉後から大脳皮質までの障害で低下すると考えられて いる.

(4) 両耳分離能検査は内側鉒状体から大腷皮質までが 関与すると考えられており，一側の分離能の低下は反対 側の側頭葉の障害を推定し得る。太田 ${ }^{27}$ 柱両耳分離能は 最も高次の中枢機能であると述べている。

上記検查項目中，(1)方向感検查，(2)歪語音明瞭度 検 查（3)両耳合成能検查梳いずれも，後迷路性難聴の診断 には役立つが，その病変部位診断にはある程度の限界が あると考えられる。しかし，雨耳分離能検査は淩迷路性 経路の中でも最も高次の中枢機能と考えられているため K，大膊半球に原病巣の存在する場合が多い脳卒中症例 では診断学的に価值があるるのと考えられる。そのため に著者は両耳分離能検查を中心とし，他の聴覚検査注参 考までにした。

症例 1 は右内䅡動脈閉塞例であり，純音㯖力検查で は，平均聴力損失は右 $22.5 \mathrm{~dB}$, 左 $19 \mathrm{~dB}$ であり正常範用 内であるが，両耳分離能検查で注右耳が $100 \%$ に対し， 左耳は $0 \%$ と著明な低下を示している：この症例では右 大脂半球のある程度広範な障害が考えられるが，分離能 检查加らも明らかに側頭葉を中心とした広筑な障害を推 定し得た，方向感検査では 10/21，歪語音明膫度は左耳
で30\%と両検查で低下しているが，これは右大媨半球に 障害があるために低下を示したのか，媨幹に何らかの影 響が加わつたためかは明らかではない

症例 2 の膗出血の外側型障害では，その障害部位は内 包より外側であり，平均聴力損失住存 $5 \mathrm{~dB}$, 左 $\mathrm{OdB}$ で正

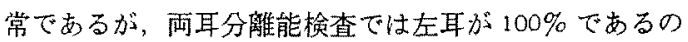
に右耳は $30 \%$ と著明な低下を示している。この症例で は，大媨皮質の障害としての失語症を伴つているために 脳出血であれば，当然大脳皮質下，皮賢にお上ぶ外側型 障害が考えられ，それに分離能の低下を加えると，さら に明らかになると考えられる。

岡崎は25)，側頭葉に障害のある症例の両耳分離能検查 加ら，一側耳の分離能低下は障害された側頭葉上反対側 の耳に欢られ，側頭葉の中でも上側頭回，中側頭回の皮

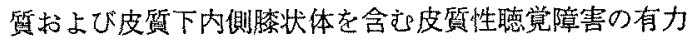
な検查法であると述へてている，上側頭回は嵒覚野と関連 し, 中側頭回と共に，ウェルニッケの感覚性失語症を起 こす局在部位と考えられている。

脑卒中症例143例の両耳分離能検查の結果を，0３0\% を異常例，40７0\%を境界例，80\%以上を正常例とした のは，大略上記の3群に分類されたためである。境界例 のうち，40\%と70\%ではかなり巽なるが，その判定に際 しては他の㯖覚検查結果や神経学的所見を参考にする必 要がある。乙の理由は，老人になると特別な矤患がなく ても分離能は低下する傾向があるからである。

聴覚検查が自覚的検査である以上，脳卒中症例のごと く比較的高齢者に多く起こり，程度の差こそあ九何らか の形で動眽硬化性疾香や失語症などを合併している場合 には，唡查結果に信頼性を欠くことが多い．

脳出血におるいて，雨耳分颜能は外側型では異常を示す 例が多いが、外側型と混合型を比べると明らかな差は認 められなかつた。しかし，脳出血症例のらち，分離能の 不良を示し、それに大脳皮質障害として失語症などを合 併している場合は，出血は大脳皮领下，皮質に拉よび， 外側型の障害が推定され得る。すなわち, 病变の拡がり をある程度推定させると考えられる。

脑主幹動脈閉塞による㨫硬塞症例では，ある程度広籍 な大䶼の障害が考えられる場合が多いが，雨耳分離能検 查では高度の異常を示寸例が多く，不能例もあり，正常 例は一例のみであつた：この正常例は前大脑動脈の閒塞 例であり，側頭葉が前大脳動脈の支配領域でないため上 考えられる。

一般に，㣪迷路性難㯖の診断において，それぞれの検 
査から障害部位を診断すること虫困難であるが，媨卒中 症例のごとく天幕上障害で梳雨分離能莬查を中心にし た聴覚検查に一般神経学的所見を組みあわせることによ りある程度障害部位診断は可能である。

$$
\text { VI とめ }
$$

腷卒中発作後, 脳幹障害の有然および程度は尒後判定 に重要であり，脳幹に出血や硬塞が起こると，最初から 重症で予後もきわめて悪いしかし，従来の検查法では

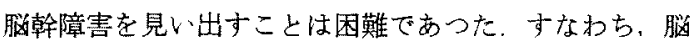
幹障害の㟝断には病紧徴候としての脳神経症状や錐体路 を中心とした運動系や知覚采の神経学的検查，あるいは 脳血管撮影や脳室撮影の補助的診断法があるが，これら の検查法では異常が認められないことが多かつた。

この上らな症例に神経耳科学的検索を行うと，その病 変が天幕下にあれば当然であるが天幕上にあつても，異 常所見を呈することが多く，さらに天幕上あるいは天幕 下の障害の程度とその関連性についても何らかを示唆す ることが少なくなかつた。すなわち，著者の施行した前 庭平衡系拉上び聴覚系の検查から，脑卒中症例の中枢前 庭系や聴覚系に異常を認めることが多く，それにより天 幕上お上び天幕下の障害について診断学的意義を得るこ とか゚できるようにになった。

(1) 㮸出血症例の約半数に，何らかの眼振が認如ら机 たが，出血部位が外側型でも混合型でも眼振出現に関し 明らかな差は認められなかつた。これは这幹への2 次的 な影響のためと推定される。

（2）視運動性眼振検查にて，脳出血症例の外側型上り 混合型に OKP 所見の不良例が多かつた。乙れは，出血 部位推定の一助となり得ると考えられる。

（3）脳出血症例の䄪半数に耐耳分離能の異常を認め, 外側型では異常を示す例が多いが, 外側型と混台型を比 ベると著明な差を認めなかつた。しかし，分㒕能の異常 を示すものはその病変の搪がりを推定させ，失語症が合 併しているならば，出血部位は皮犋下のみならず皮質に までおよんでいる上考えられる。

(4) 脳硬塞症例に捛いて, 約半数以上に何らかの眼振 妾認めたが，闒塞部位上眼振出現について一定の関倸は 認められなかつた。

(5) 脳主幹動脈の閉塞部位にかか力らす， OKP 所見 の不良例ばかりがあり，境界例や良好例が認められなか

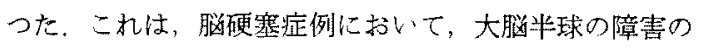
大ささをある程度示しているものと考えられる。

(6) 視渾動性眼振㭘查拉上び両耳分離能検查において
多くの症例に検査不能例が認められた。これは天幕上障 害の大きさを示すものと考えられる。

故に，脳卒中症例において，従来の一般神経学的諸検 查に加えて，前庭平衡系および聴賞系の検查を施行する ことにより，その障害部位と抗がりをより明確に䛦断し 得, 更に, 脑幹障害の有無技上び程度も推定することが 可能で，予後判定の一助にもなり得ると考えられる。そ れ故に，著者はこれら神経耳科学的諸桙查は天幕下障害 のみならず，天幕上障害にも診断学的意義があるものと 結論する。

\section{文献}

1) 岡本途也他：特殊㯖力検查の能率化火ついて, 耳 展，12；57-63，1969.

2）金谷春之他：頍衤内出血一その見わけ方と患者の报 方, 治療, 53；1721-1726, 1971.

3）金谷春之他：高血正性膇出血の血腫局在（深澾破坡 度）よりみた外科的療法と元の意義，臨床之研觉， $47 ; 1644-1649,1970$.

4) 小野寺英樹：高血王性脑出血の外科的治療比関寸る

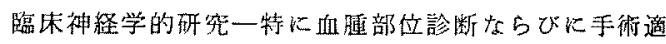
応の钼点上り一、神経研究の進步，3；647-659，1969.

5 ）龟山正邦：神経病学一血管系を中心一，日本医来 新報, $2603 ; 3-16,1974$.

6) 德增厚二: 水平性自発眼振の方向ならびに水平性語 発眼振の出やすい万向飞閣寸る神経学的意義, 耳喉, $40 ; 89-99,1968$.

7)許瑞光：眼振拉上び視連動性眼振㭘查の診断学的意 義について一謴部外伤例を中心にして一, 脳・神経外 侮, 3;319-333, 1971.

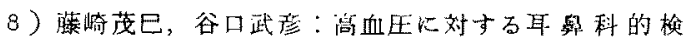
討, 日耳鼻, 64；1701-1707，1961，b.

9）沖中重雄他：脳卒中のすべて，南江堂，1972.

10) Cogan, D.G. and Loeb, D.R.: Optokinetic response and intracranial lesion. Arch. Neuro, and Psych. $61 ; 183-187,1949$.

11) Enoksson, P.: Optokinetic nystagmus in brain lesions. Acta Ophthal. $34 ; 163-184,1956$.

12）森本正紀他：平衡神経の榆査法一乞の理論々实際 一, 金原出版, 1970.

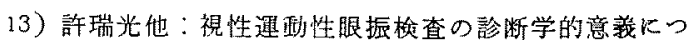
いて一大細半球に括ける視野の障害を有する定例につ いて，日耳嘪，72：406-407，1969.

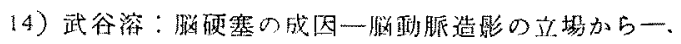


日本臨林，25；16-24，1967.

15）重山正邦：脳底部動脈 variation の臨床病理学的意 義, 神経進歩, 5；758-767，1961.

16) Torvic, A. et al.: Thrombotic and embolic occ lusions of the carotid arteries in an autopsy series. Part 2. Cerebral lesions and clinical course. I. neurol. Sci $410-432,1966$.

17) 北原正章他：視運動性眼振以出ける固視の形態，耳 臨休, 64; 67-72, 1971.

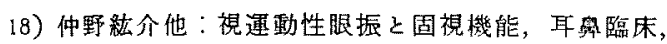
$64 ; 434-542,1971$.

19)勝木保次他: 生理学大系IV一感覚の生理学一。医学 輷院，1967.

20) Gay, A.J., et al.: Eye movement disorders. The C.V. Mosby Company, Saint Louis, 1974.

21) Bach-Y-Rita, $P$, et al.: The control of eye movenents. Academic Press, New York and London. 1971.

22）小松崎篤：橋部脳障害の診断一平衡神経学の立場上 ○一，日耳䊆，73；1110-1111，1970。

23) Weber, E.G.. Theory of hearing. Dover publication, inc. New York, 1970.

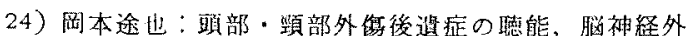
鹪，3；155-162，1971.

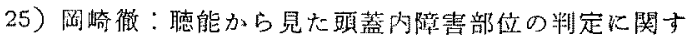
る臨果研究，日耳鼠，73；599-624，1970.

26）娜替一郎：神経耳科学，第18回日本医学会総会会 誌, L-14；86-93, 1974.

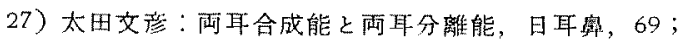
襍 $3 ; 29-50,1966$.

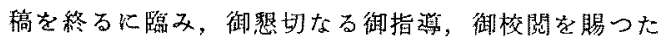
恩師岡本途也教授飞梁く感謝致します。䅂始温か心 御指尊, 御助言を頂き立した東京递信病院脳神経外科, 昭和大学耳鼠咽倨科部瑞光請師に心から感謝致します。 さらに本研究の機会を与之て下さつた太田綜合病院附属 然海総合病院院長太田舜二博士はじめ各位の御協力に心 より御礼申し上げます。

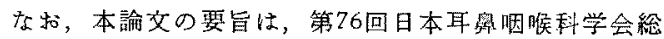
会拉よび第20回日本オージオロジー学会総会に扣いで発 表した。

（原稿受付 昭和50.10.1 日） 